\title{
Zika Virus Infection in East Asia: Current Situation
}

\author{
Viroj Wiwanitkit ${ }^{1,2,3,4,5}$ \\ ${ }^{1}$ Visiting Professor, Hainan Medical University, P.R. China; \\ ${ }^{2}$ Visiting Professor, Faculty of Medicine, University of Nis, Serbia; \\ ${ }^{3}$ Adjunct Professor, Joseph Ayobabalola University, Nigeria; \\ ${ }^{4}$ Honorary Professor, Dr DY Patil University, India; \\ ${ }^{5}$ Professor, Senior Expert, Surindra Rajabhat University, Thailand.
}

*Corresponding Author: Professor Viroj Wiwanitkit. Wiwanitkit House, Bangkhae, Bangkok 10160, Thailand. Email: wviroj@yahoo.com.

\begin{abstract}
Zika virus infection is a emerging public health problem. It mainly affects tropical Latin and South American countries causing thousand cases of infections. It is currently viewed as the most significant emerging global health emergency. Zika is seen in other regions. The article provides an overview of East Asia and a summary of the current Zika situation in southeast Asia. Zika has been reported in East Asia. None seem to have been contracted locally and were "imported" or traveler cases highlighting the importance of travel medicine. As global warming extends mosquito habitat areas local transmission and Zika outbreaks in East Asia seem likelier to occur.
\end{abstract}

Key Words: Zika virus; Infection; East Asia

http://mo.qingres.com

\section{GOPEN ACCESS}

DOI: $10.20900 / \mathrm{mo} .201600011$

Received: March 9, 2016

Accepted: May 13, 2016

Published: June 25, 2016

Copyright: $\odot 2016$ Cain et al. This is an open access article distributed under the terms of the Creative Commons Attribution License, which permits unrestricted use, distribution, and reproduction in any medium, provided the original author and source are credited.

\section{INTRODUCTION}

Zika is currently the most problematic arbovirus. First reported in 1947 in Uganda it is medicine's newest major challenge having been recognized as an important problem in the last few years ${ }^{[1,2]}$. Zika is generally a mild infection and can be self-limiting. The present series of problems started with a major outbreak on Yap Island, Micronesia which extended into other Pacific regions in 2013-2014 ${ }^{[3,4]}$. A large outbreak in tropical America affecting more than million people resulted 
in the World Health Organization (WHO) calling for an urgent response to this emerging disease ${ }^{[5}$,

${ }^{6}$. Fetal abnormalities following an infection during pregnancy is the most important consideration ${ }^{[7]}$.

It is widely accepted as a disease calling for global management. It is seen in other regions. East Asia, with the greatest human population is one such area. Any disease emerging in this area becomes an important global problem. This article summarizes the current Zika situation in East Asia.

\subsection{Zika Virus Infection in East Asia}

East Asia, not itself a tropical region, it adjacent to Southeast Asia and The Pacific region where many tropical diseases including Zika.

Significantly, the mosquito vector carries Zika, the Aedes species is found in East Asia. A recent report from China is the good example ${ }^{[8]}$. Its presents the current situation of Zika in East Asia.

\subsubsection{China}

China is the most populous country in the world. The existence of a mosquito vector in China is worrying ${ }^{[8]}$. Zika is already reported in China. The first case was an imported case reported by Deng et al. ${ }^{[9]}$. The male patient "was admitted with chief complaint of fever for 9 day" "[9] . His history showed that he had been "bitten by mosquitoes during his business trip in Venezuela since January 1st, where Zika virus disease was spreading" ${ }^{\text {[9] }}$. This is the first case reported in East Asia. It is also a case study of the use of Chinese Medicine for managing of the infection ${ }^{[9]}$. Following this first case, there are also some other imported cases including infected children. Zheng, et al. reported infected children with history of traveling to endemic area. In this report, the infection was mild and self-limited ${ }^{[10]}$. A history of travel to endemic American countries is the main clue in the diagnosis of all imported cases in China ${ }^{[11,}$ ${ }^{12]}$. The correspondence between travel and infection in the cases in China reports many attempts of disease investigation and controls ${ }^{[13]}$. This includes a concern regarding the mosquito vector. Gao et al., noted that "strict measures should be taken to reduce the Aedes albopictus density for the effective control Zika virus spread" ${ }^{[14]}$.

Taiwan is a one of the largest islands off the southern East Asian coast. As of this writing there has been one case report of Zika in Taiwan, China. A Thai traveler, from a tropical endemic area, carried the disease into Taiwan. Although detected at the airport, it became a large local public health concern ${ }^{[15]}$. This confirmed the need for strict screening at immigration ports for people coming from an Zika endemic area.

\subsubsection{South Korea}

Presently there are no know reports of Zika in South Korea.

\subsubsection{North Korea}

North Korean health issue reports are usually quite limited. As of this writing there are no official reports of in, or from, North Korea.

\subsubsection{Japan}

Japan is an East Asian island country. An imported Zika virus case has been seen in Japan. Shinohara, et al. reported a Japanese patient with infection upon their return from Thailand ${ }^{[16]}$. Kutsuna, et al. reported similar cases with a history of tourism trips to French Polynesia ${ }^{[17]}$. Since Southeast Asia and the Pacific islands are popular tourist resorts and the Zika virus infection already exists there, there is little doubt that tourists might get the infection and carry it back to become an imported case in their home country.

\subsubsection{Mongolia}

Mongolia is a landlocked country in East Asia between Russia and China. The climate is dry and it is located far from the Zika tropical endemic areas. There is currently no report of Zika virus in Mongolia.

\section{CONCLUSION}

Although non-tropical East Asia already has a few of Zika. All the cases are imported by travelers from an endemic area. The importance of travel medicine cannot be overstated. Strict infection control processes at immigration ports must be implemented. Global warming and the likely extension of mosquito habit areas is likely which might lead to the local transmission and outbreak of Zika virus infection in East Asia in the near future. 


\section{CONFLICT OF INTERESTS}

The authors declare that they have no conflict of interests.

\section{REFERENCES}

1. Kindhauser MK, Allen T, Frank V, Santhana RS, Dye C. Zika: The origin and spread of a mosquito-borne virus. Bull World Health Organ. 2016; 94(9): 675-686C.

2. Dick GW, Kitchen SF, HaddowAJ. Zika virus(I). Isolations and serological specificity. Trans R Soc Trop Med Hyg.1952; 46(5): 509-520.

3. Oehler E, Watrin L, Larre P, Leparc-Goffart I, Lastere S, Valour F, Baudouin L, Mallet H, Musso D, Ghawche F. Zika virus infection complicated by Guillain-Barre syndrome - case report, French Polynesia, December 2013. Euro Surveill. 2014; 19(9): 4-6.

4. Lanciotti RS, Kosoy OL, Laven JJ, Velez JO, Lambert AJ, Johnson AJ, Stanfield SM, Duffy MR. Genetic and Serologic Properties of Zika Virus Associated with an Epidemic, Yap State, Micronesia, 2007. Emerg Infect Dis. 2008; 14(8): 1232-1239.

5. Enfissi A, Codrington J, Roosblad J, Kazanji $M$, Rousset D. Zika virus genome from the Americas. Lancet. 2016; 387(10015): 227-228.

6. Adibi JJ, Marques ET Jr, Cartus A, Beigi RH. Teratogenic effects of the Zika virus and the role of the placenta. Lancet. 2016; 387(10027): 1587-1590.

7. Gulland A. WHO warns of risk of Zika virus in Europe. BMJ 2016; 353: i2887.

8. Jin LQ, Li D. A recent survey of mosquito fauna in Guangdong Province, southern China, with a review of past records. Med Vet Entomol. 2008; 22(4): 359-363.

9. Deng $Y$, Zeng L, Bao W, Xu P, Zhong G. Experience of integrated traditional Chinese and
Western medicine in first case of imported Zika virus disease in China. Chinese Critical Care Med. 2016; 28(2): 106-109.

10. Zheng CG, Xu Y, Jiang HQ, Yin YX, Zhang JH, Zhu WJ, Liang XJ, Chen MX, Ye JW, Tan LM, Luo D, Gong ST. Clinical analysis of two cases of imported children Zika virus infection in China. Chinese J Pediatrics. 2016; 54(5): 375-378.

11. Liao Y, Zeng ZL, Hu GL, Yang JP, Yuan H, Li JH, Zhang $X M$, Huang RF, Liu XQ. Survey of the first case of Zika virus disease in the mainland of China. Chinese J Epidemiol. 2016; 37(5): 593-596.

12. Dong XJ, Sun JM, Lou LQ, Zhu ZH, Zhu LB, Lou T. Survey of the third Zika virus disease case in the mainland of China. Chinese $\mathrm{J}$ Epidemiol. 2016; 37(5): 597-599.

13. Gao Q, Xiong CL, Zhou YB, Cao H, Jiang QW. Infestation status Aedes albopictus and related mosquito-borne infectious disease risk in central urban area in Shanghai. Chinese $\mathrm{J}$ Epidemiol. 2016; 37(5): 600-605.

14. Liu XQ, Zhu MM, Liao $Y$, Zhang TC, Huang $H$, $\mathrm{Hu}$ GL. Investigation on the preventive and control strategies against the first imported case of Zika virus infection in China mainland. Chinese J Prev Med. 2016; 50(6): 547-549.

15. Huang AS, Shu PY, Yang $\mathrm{CH}$. A new reportable disease is born: Taiwan Centers for Disease Control's response to emerging Zika virus infection. J Formos Med Assoc. 2016; 115(4): 223-225.

16. Shinohara K, Kutsuna S, Takasaki T, Moi ML, Ikeda M, Kotaki A, Yamamoto K, Fujiya Y, Mawatari M, Takeshita N, Hayakawa K, Kanagawa S, Kato Y, Ohmagari N. Zika fever imported from Thailand to Japan, and diagnosed by PCR in the urines. J Travel Med. 2016; 23(1): pii: tav011.

17. Kutsuna S, Kato Y, Takasaki T, Moi M, Kotaki A, Uemura $\mathrm{H}$, Matono T, Fujiya $\mathrm{Y}$, Mawatari M, Takeshita N, Hayakawa K, Kanagawa S, Ohmagari N. Two cases of Zika fever imported from French Polynesia to Japan, December 2013 to January 2014 (corrected). Euro Surveill. 2014; 19(4): pii: 20683. 